\title{
Determinants of customer intentions for online shopping: A Study from Pakistan
}

\author{
Muhammad Rizwan (Corresponding author) \\ Lecturer, Department of Management Sciences, \\ The Islamia University of Bahawalpur, Pakistan \\ E-mail: rizwan.arshad@iub.edu.pk
}

Syed Muhammad Umair

Department of Management Sciences, The Islamia University of Bahawalpur, Pakistan

Hafiz Muhammad Bilal

Department of Management Sciences, The Islamia University of Bahawalpur, Pakistan

MueenAkhtar

Department of Management Sciences, The Islamia University of Bahawalpur, Pakistan

Muhammad SajidBhatti

Department of Management Sciences, The Islamia University of Bahawalpur, Pakistan

Doi:10.5296/ jsr.v5i1.6565 URL: http://dx.doi.org/10.5296/ jsr.v5i1.6565

\begin{abstract}
Time and trend wait for none. We are in 2013 where time is money. In past people travels hundred miles for transactions, which was a time consuming activity. This courage's people to shop online instead manual shopping. Online Shopping (OS) has totally changed the people perception about shopping. Generally the objective of this research is to discover the influence of different variables on online shopping intention. Specifically the aim of this study is to find the impact of Prior Online Shopping Experience (POSE) on Perceived Ease Of Use (PEOU), Perceived Usefulness (PU) and Perceived Risk (PR) then PEOU, PU and PR influence on Attitude Towards Online Shopping Intention (ATOSI) and farther the
\end{abstract}


influence of ATOS on Online Shopping Intention (OSI) . A questioner survey has been conducted to test the hypothesis. The sample of 200 respondents received through these questioners. The result shows that POS didn't has any effect on PU, PEOU and PR while PU and PEOU has positive significant effect and PR has a negative effect on ATOSI. This study also found that ATOSI has a positive significant effect on online shopping intention.

Keywords: Attitude towards online shopping, perceived ease of use, perceived enjoyment

\section{Introduction}

The internet is one of numerous non-store measures commonly used by today's users for shopping. Retailing electronic (e-tailing) experienced impressive expansion in recent years because of clear advantages for customers and retailers, such as shopping at home all day, reducing dependence on store visits, saving travel costs, expanding market area, reducing overheads, support customer relationships and offers a wide range of products (services). Where customers visit various websites offering different products for sale, select the product, order the products make, makes payments credit cards and finally seller physically delivered the products.

Adoption of e-commerce relies on the profile of latent consumers as not all consumers accept an modernism at a time (Rogers, 1962).

In 1990, Tim Berner-Lee formed the first website. Also in 1994 the German corporation announced its first virtual store. Once a product is selected from the website, payments are made through the internet, sometimes by sign up for permanent online accounts. Payments are also made through mobile phones and landlines by electronic money that is of various types and through credit cards. After the payment process, the products are delivered through downloading and mailing. OS is becoming increasingly popular. The widespread use of research on OS aimed at to understand the reason which drives people from technology oriented towards OS. The hour of the need is to understand the factors which influence OS.

Technology Acceptance Model (TAM) model has been developed by Davis, (1989) to understand the popularity of OS. TAM is an evidence system concept that represents how the consumers start using new information technology (IT). TAM is broadly used to explain individual's intention and real use of IT. The main edge for customers to buy products and services online is the network, a form of IT.Among all theories and models, TAM has been viewed the commonly used and the most prominent model for understanding the electronic commerce from a customer oriented view. Many researches in the field of OS use the TAM (Burner and Kumar, 2005 and McKechnie et al. 2006). The primary purchase of the revision is to lengthen TAM by including new variants as recommended by Davis, (1993) and further investigate the relationship of attitude and intention with the help of moderating variables as mentioned by (Chen, 2007; Cheema et al., 2013).

TAM posits that two of a person's views around the usefulness and usability of the computer system affects / attitude towards usage, which in turn lead to his / her intentions to use and 
create / authorization of, use (Davis et al., 1989).Some researchers have standard PU as utilitarian and hedonistic values, respectively, and their attitudes and behaviors related to customers intend OS (Ahnet al, 2007. Lee, 2005). Though, the effects of PU and satisfaction on intention to repurchase are not clear under OS.

PU is defined as the degree to which the consumer or improve functional performance of transactions. According to Bhattacherjee (2001), a person is more expected to intend to carry out the continuous use where such use is perceived to be valuable. Previous exploration shows that PU has a significant effect on customer loyalty desire (Cyret al., 2006).

Perceived Ease of Use (PEOU) analyzes customer knowledge that consumption of this technology is free of effort. PEOU refers to the degree to which the consumer trusts that the OS will be painless. TAM means that all other factors being equal, an OS web is considered easier to use is extra possible to cause an imagination of utility. The degree to which it increases the ease of use leads to better performance. Preceding studies have provided evidence for the effect of the PEOU on PU under the OS (Devarajet al, 2002. Gefenet al 2003, Pavlou 2003, Cyret al., 2006).

In 1994, (Dowling and Staelin) define PR as "PR is the picture buyer unpredictable. Shopping online has associated with carrying the risk. Risk perception of online shopping is common consumers a multidimensional construct individual is worried about the potential risk associated with a new kind of shopping over the Internet. In the case of OS, the perceived risk significantly affect the customer's intention (Lee and Clark, 1996).

Now we can assume that the factors mentioned in the preceding paragraphs should focus and awareness should be created in the OS and the OS is obviously easier to make purchases online and people want to live well, but because the lack of information and the risk factor of personal data leakage sand, people are reluctant to do in the OS. The aim of this research is to investigate online product ATOSI using and Fishbein (Ajzen and Fishbein, 1980) theory of reasoned action Ajzen. According to this theory, a person's attitude toward a behavior that is a significant determinant of his / her intention to comply with this behavior, which was seen as a direct prediction of his / her actual behavior.

\section{Literature Review}

\subsection{Online shopping Intention}

OS is a process where the customer purchases products and services directly from the seller using the internet as a medium. OS is a type of e-commerce where the customer buys goods without any intermediary services. OS is an innovative form of trade that takes place on the internet. Where customers visit various websites offering different products for sale, select the product, order the products make, makes payments via credit cards and finally seller physically delivered the products. People are mostly more intend to shop online as it saves their time and they can do the work of hours in minutes still confined to the office or home.

OSI is a dependent variable which is influenced by the other independent variables such as, attitude, PEOU, PU, PR and POSE. Attitude measures how people show their behavior 
towards online shopping. Factors affecting OS attitude of people have researched and documented within the traditional literature of consumers. An analysis of experimental researches in this field shows that the theories of logical action (Fishbein and Ajzen, 1975) and Acceptance Model (Davis, 1989) are some of most popular theories used to illuminate the behavior of the OS (Limayem et al., 2003; Ahmed et al., 2013).

OS behavior is individual behavior to buy on-line. Folks who catch it easy to use, useful and pleasant can agree to take online shopping. Model of acceptance of the technology is used to understand the factors affecting online shopping. These variables perceived usefulness, perceived ease of use and some others.

\subsection{Attitude towards Online Shopping Intention (ATOSI)}

ATOSI defined as positive or negative emotions of consumers in the hillside achievement or emotion that causes a predisposition to respond positively or negatively to a stimulus buying behavior on the Internet (Chiu et al, 2005, Schlosser, 2003). The version given by Davis et al. (1989) includes the attitude, as an intermediary between perception and behavior explanatory. The word "attitude" symbolizes the overall level of favorability or un-favorability towards external stimulus. Attitude is an indicator that reflects the liking or disliking of a person regarding any object (Ajzen and Fishbein, 1980). The ATOSI has a substantial impact on the intent to web buying (Limayem et al. 2000). Different studies also confirm the similar results for the link between attitude and OSI. Attitude makes it more convenient to shop online; those people who have a complete trust on OS will show their positive ATOSI.

\section{H1: Attitude has a positive effect on online shopping.}

The Technology Acceptance Modal (TAM) is a theory of information systems that models how users come to accept and use the technology. The model recommends that when users are presented with a new technology, a number of aspects that effect their decision about how and when to use it.

\subsection{Perceived usefulness (PU)}

This was defined by Fred Davis as "the degree to which a person believes that using a specific system would improve his job performance (Davis 1989). Looking ahead to electronic purchases, PU is the customer perception that online shopping or performance will be enhanced.

The application of the concepts of PU in the context of electronic commerce, the "utility" is the efficiency with which Internet shopping helps consumers to do their job. According to (Barkhi and Wallace 2007), in addition to low prices, extensive variety of merchandises and brands and minimal cost of finding facts that may contribute to the opinion of consumers about the value of buying clothing items an online store, compared to buying aold-fashionedstore. Davis et al. (1989) identified PU as key factors influencing the acceptance of the system information. As emphasized in numerous empirical studies, PU of a system is a dominant feature that significantly affects the voluntary or mandatory acceptance of a person (Gefen, 2003, Venkatesh, 2000). 
PU signifies its estimate of the user advantages of using the system utility, such as simplification of the system's efficiency and effectiveness in carrying out a particular task. While on the other hand; it shows the implementation of a person or expectation for increased performance through the use of the system. Similarly, one could define OS as client's subjective probability that the use of a virtual store would have increased value andcompetency throughout the buying procedure (e.g., find information, compare orders,prices and payments, package tracking and client access intangible products like services) (Zhou et al., 2007).

Many scholars commented that the OS is a aim-oriented activity of a certain size, and extrinsic motivation as the physical benefits (e.g., the treatment non expensive, time savings and convenience) or non-physical benefits (e.g., watch all the amenities, shopping without problems unless reliance on tangiblemarkets, contact to merchandise information and accessibility of aextensive range of products) cause purchase intentions especially online customers (Lim and Dubinsky, 2004, Wolfinbarger and Gilly, 2001).

Therefore, current approach based on observedfacts and the usefulness of TAM used as a substitute for the extrinsic stimulishows positive effect on the behavior of the consumer to obtain OS (O'Cass and Fenech, 2003). Though, consider the advantages of online shopping experience may leak, unless OS gives the estimated return on economic investment (e.g., pay for Internet connection, remains connected the network for finding and differentiating products and prices, learn to utilize electronic markets) made by consumers. Specifically, it relates to the work efficiency, productivity (which means saving of time) and the relative importance for the working system of the person. The PU influence an individual's ATOSI.

\section{H2: Perceived usefulness of the internet as a shopping channel has a positive influence on attitudes towards the online shopping.}

\subsection{Perceived ease of use (PEOU)}

PEOU refers the degree to which the system require very less or minimal effort to use, the effort is meant to contains both intellectual and physical effort, and how simple it is. (Davis et al., 1989).PEOU is also described as outspread to which an individual discovers a work free of effort. Effort is a limited source that is to be paid to several actions by somebody answerable for the actions (Radner and Rothschild, 1975). Ease of use tells that how simple it is to use the Internet as a shopping channel (Monsuwe et al., 2004).

PEOU discusses the customer's awareness that consuming this technology is unrestricted of efforts. As the PEOU of the original cooperative media, intensifications attitude towards media becomes additional positive. PEOU positively affects attitude towards online shopping. Davis et al. (1989) argued that improvements in ease of use will also improve performance. To the extent that increases the ease of use leads to better performance ease of use, will have a direct effect on PU and behavioral intention (Venkatesh and Davis, 2000). 
Szymanski and Hise (2000) used focus groups of consumers which shop online to identify the satisfaction related to online shopping and identified as the result of consumer perceptions of online convenience (ease of use), goods, web design, and financial security . Customers see the Internet as a way to shop effectively and efficiently. The higher the website can provide comfort in searching and obtaining products online, consumers more pleased. Positive factors include merchandising element includes large variety of products, accessibility of products online, and the ease of comparative shopping and search for the preferred products. Commercial websites are designed by the good organization, ease of navigation, the lack Lutter, and quick access. Security Credit cards are the most dominant concern advent of electronic commerce (Kwon and Lee, 2003, Chain Store Age, 1999, Szymanski and Hise, 2000).

Szymanski and Hise (2000) found that the level of economic consumers feel safe with online retailers related to e-satisfaction. Elements that encourage consumers to buy products online including web design ease of navigation and finding information, security guarantees and return policies clearly (Siddiqui et al., 2003). Popular literature sources mention avoid holiday crowds, low prices, easy comparison shopping, low shipping cost, timely delivery, the tax-exempt status, avoid bad weather, improving information security, improve customer service customer convenience and time savings, and fast e-mail response key reasons for the increase in SG (Lorek 2003 Magee, 2003, Maloy, 2003, Retail Merchandiser, 2003, Rowley and Okelberry, 2000), although the threat of credit card fraud is a concern and the potential for reducing consumer confidence is real - especially in the UK (Magee, 2003). Moreover, the increase in the number of buyer's line is greater than the increase in Internet users, demonstrating that most users are comfortable OS (Magee, 2003).

When customers find that the interaction with the OS is easy and web site is easy to find information about the products and pay online, they prefer OS. The conclusion is that PEOU affects significantly. OSI Therefore solicitation or system is more likely to be accepted by the operator if it is perceived by him to be easier to use.The PEOU influences an individual's ATOSI.

\section{H3: Perceived ease of use of the internet as a shopping channel has a positive influence on attitudes towards the internet as a shopping channel.}

\section{H4: Perceived ease of use positively affects perceived usefulness.}

\subsection{Perceived Risk (PR)}

In 1994, (Dowling and Staelin) define PR as "PR is the buyer or we can say unpredictable box unchanged to adverse results of products and services. For OS different types of the risks that consumer perceive in his mind, like the wrong use of credit card data or personal information. Perceived risk refers whether the goods or service does not work as expected 
(Horton, 1976). According to (2003) the evolution of risk Forsythe and Shi product is the most important barrier to do so.

The perceived risk of product performance will change with the objectives related to the purchase and use of products (Dowling and Staelin, 1994). A comparison of risk factors with OS preference concludes that PR will be higher OS compared with purchases. PR can be two dimensional, for example, perceived social risk or perceived risk devices (Geuens et al, 2003)., (Venkatesh and Davis, 2000), entrepreneur perceived risk (Cheung and Lee, 2000 Lim , 2003) and perceived technological risks (Lim, 2003). According to (Miyazaki and Fernandez, 2001) found that consumers PR studies is much higher in OS compared to online shopping or we can say that shopping and PR are obstacles to OS (Cho, 2004, Forsythe and Shi, 2003).

The perceived risk by consumers in online shopping is greater than the trade of traditional retail stores, due to the distribution of electronic commerce and the unfriendly nature (Zhou et al., 2007). PR adversely affects consumer behavior to shop online (Bhatnagar et al, 2000 Park et al, 2004). Lee and Huddleston (2006) projected five dimensions of comprehensive PR if OS: time, privacy economic, performance and social risk. All these risks persuade their decision to buy on-line. Therefore, the possibility to shop online is decreasing due to increase in perception of risk.Several researches elaborate the security concerns of the customers like misappropriation of the individual's information and credit card influence the customer decision to do OS (Malhotra et al. 2004 and Drennan et al. 2006) examine the general risk perception of OS with the help of two elements such as privacy and security risk.

The ideas for the PR determine consumers have a sense of psychological uncertainty when you can see the result of a purchase decision (Bauer, 1906, Cox 1976). The research found that the PR of the ambiguity of the customers regarding the purchase decision and cannot meet their needs and what they wanted to be. According to (den Poel and Leunis (1999) PR associated with online business person who is negatively related to the consensus to select OS.Garbarino and Strahilevitz, (2004) try to estimate the risk associated with the customer personal information misuse and illegal use of credit card. Therefore risk related to these conditions affects attitude towards OS.

\section{H5: Perceived risk towards online shopping has a negative influence on online shopping.}

\subsection{Prior online shopping experience (POSE)}

Previous research shows that make directly affects the purchase intentions of consumers of Internet (Eastlick and Lotz, 1999, Weber and Roehl, 1999). More experienced customer with OS and more satisfied they are towards the latest online trading experiences, purchase larger volume and more likely to purchase again and again (Park and June 2003. Brown et al, 2003). Successful experiences also enhance the consumer perception on the usefulness, 


\section{Macrothink}

ease of use and minimize the PR related towards the OS. When consumers use Internet, it adjust their perception as a means of shopping in a positive direction (Monsuwe et al., 2004).Under OS, consumers evaluate the shopping experience of their perceptions of product related information, payment conditions, delivery terms, the service existing, risk, security / privacy, navigation, entertainment (Burke, 2002. Monsuwe et al, 2004).

Past research shows that bring Internet directly affect purchase intentions of consumers (Eastlick and Lotz, 1999) they are satisfied with the latest online shopping experiences, purchase large volume and more likely to purchase again and again (Park and June 2003, Brown et al., 2003). Satisfactionalso enhances consumer perception towards the usefulness, ease of use and decrease the PR related to the OS. When a customer gets experienced by the internet it will adjust its perception to shop online.

In light of the previous literature, we have developed the following hypotheses:

H6: Prior purchasing experience positively affects the perceived usefulness of online shopping.

H7: Prior purchasing experience positively affects the perceived ease of use of online shopping.

H8: Prior purchasing experience negatively affects the perceived risks of online shopping.

H9: Prior purchasing experience positively affects consumer online shopping Intentions. 


\section{Model}

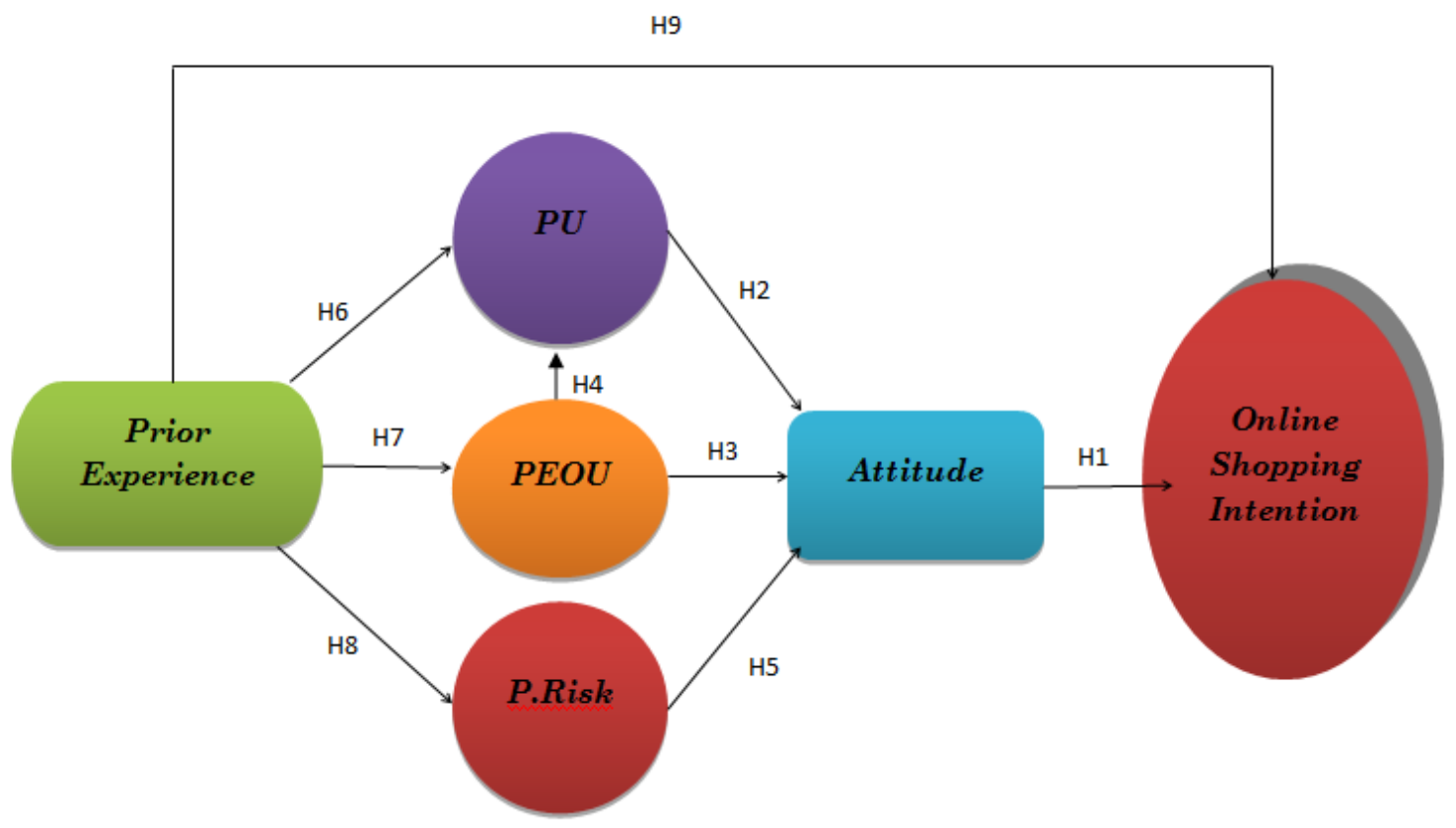

\section{Research Methodology}

Current research is descriptive in its nature. Descriptive research can be explained as a description of somewhat, some phenomenon or any specific situation. Descriptive studies are surveys that describe current condition, rather than the interpretation and decision making (Creswell, 1994). The main purpose of the research is descriptive proof developed cases reflect the current situation. This research gives information on the condition and focuses on the past or the present course, for example the quality of life in a community attitude or customer for any marketing activity (Kumar, 2005).

\subsection{Sample/Data}

In order to collect the data for understanding the situation about adoption of OS, a sample of 200 respondents will be requested to play a part in a self-questionnaire. The populations for current research are internet users in Pakistan.

This study uses a non probability sampling technique that is sampling convenience. Convenience sampling is a sampling technique that obtains and collects the relevant information from the sample or the unit of the study that are conveniently available (Zikmund, 1997).Convenience sampling is usually used to collect a large number of investigations completed quickly and the economy (Lymet al., 2010). 
It has ensured that sample participants have two major titles to participate in the self-managed survey. First, the sample would use the Internet and has sufficient knowledge to Internet. Second, never buy one item by the internet, because in case of experience in the Internet market, definitely affects the attitude and behavior of the defendant.

Members selected sample of Bahawalpur Pakistan. Two main groups will aim to collect data from the sample, such as students and working professionals. The selection of students and working professionals is based on results from previous researches in OS. According to Wood (2002), young people are more interested in OS compared with others. Fresh folks can learn the skills compulsory for the OS (Hubona and Kennick, 1996).Income is also an important factor for the adoption of OS (Shin, 2009).

\subsection{Instruments and Scales}

The survey instrument of the current study address two major purposes: First is to analyze the relationship of different variables in the adoption of OS. Second, to collect information about the different characteristics of the respondents that can be used to understand the variations in different categories.

The survey instrument contains two sections. Section 1 includes different personal and demographic variables. This section will obtain the respondent's information about gender, age, income, education, status and frequency of internet use.

Section 2 includes the latent variables that are important in the current study. These variables include POSE, PU, PEOU, ATOSI, OSI and PR. This section of the study is developed based on the past literature and already used questionnaires (Table 1).

The scales of the study were adopted from the previous literature and published studies. The first three variables of the study were PEOU, PU and OSI. Each variable have three items and these scales were taken from $\mathrm{Yu}$ et al. (2005). The next variable is OSI having three items was taken from Moon and Kim (2001). The last variable is PR with seven factors and this scale was taken from Akhlaq and Ahmed, (2011).

Table1: Scales of the Study

\begin{tabular}{|c|c|c|c|}
\hline No. & Variables & Items & References \\
\hline 1 & $\begin{array}{l}\text { Perceived } \\
\text { Ease of Use }\end{array}$ & $\begin{array}{l}\text { 1. Learning to use the internet to buy a product } \\
\text { would be } \\
\text { for me, even for the first time. } \\
\text { 2. Using the internet to buy a product would be } \\
\text { easy to do for me. } \\
\text { 3. The internet would be easy to be used to do my } \\
\text { shopping. }\end{array}$ & Yu et al. (2005) \\
\hline
\end{tabular}




\begin{tabular}{|c|c|c|c|}
\hline 2 & $\begin{array}{l}\text { Perceived } \\
\text { Usefulness }\end{array}$ & $\begin{array}{l}\text { 1. Using the internet to acquire a product would } \\
\text { allow me to shop more efficiently. } \\
\text { 2. Using the internet to acquire a product would } \\
\text { allow me to do my shopping more quickly. } \\
\text { 3. Using the internet to acquire a product would be } \\
\text { useful to do my shopping. }\end{array}$ & Yu et al. (2005) \\
\hline 3 & $\begin{array}{l}\text { Online } \\
\text { Shopping } \\
\text { Attitude }\end{array}$ & $\begin{array}{l}\text { 1. Using the internet to do my shopping is a good } \\
\text { idea. } \\
\text { 2. My general opinion of electronic commerce is } \\
\text { positive. } \\
\text { 3. Using the internet to purchase a product seems } \\
\text { an intelligent idea to me. }\end{array}$ & Yu et al. (2005) \\
\hline 4 & $\begin{array}{l}\text { Online } \\
\text { Shopping } \\
\text { Intention }\end{array}$ & $\begin{array}{l}\text { 1. I will probably buy a product on the internet } \\
\text { (soon). } \\
\text { 2. The internet will probably be the medium I use } \\
\text { to do my shopping in the future. } \\
\text { 3. I intend to use the internet to buy a product } \\
\text { soon. }\end{array}$ & $\begin{array}{l}\text { Moon and Kim } \\
\text { (2001) }\end{array}$ \\
\hline 5 & Perceived Risk & $\begin{array}{l}\text { 1. The (product) would fail to perform to my } \\
\text { satisfaction. } \\
\text { 2. I would incur high maintenance costs. } \\
\text { 3. My friends and relatives would not think } \\
\text { more highly of me if I buy this (product) } \\
\text { 4. The (product) will not fits well with my } \\
\text { image. } \\
\text { 5. I would have to waste time and effort } \\
\text { getting the (product) repaired or } \\
\text { when it fails. } \\
\text { 6. Using the (product) would cause danger to } \\
\text { my health or safety. } \\
\text { 7. I would pay a high price for this (product). }\end{array}$ & $\begin{array}{l}\text { Akhlaq and } \\
\text { Ahmed, (2011) }\end{array}$ \\
\hline
\end{tabular}




\section{Al Macrothink}

\subsection{Procedure}

The questionnaire was distributed among 220 respondents in Bahawalpur, Pakistan. These respondents are selected based on the criteria above mentioned. Before giving the questionnaire, for the purpose of study and the questions were explained to the participants so they can easily fill the questionnaire with relevant answers. A total of 200 questionnaires were selected and rest of the questionnaires was not included in the further analysis due to incomplete or invalid responses. After collecting the completed questionnaires, these questionnaires were coded and entered into SPSS sheet for further analysis.

\subsection{Reliability Analysis}

Overall Cronbach's alpha of Online Shopping questionnaire items were 0.785 that is more than acceptable and recommended value 0.50 by Nunnally (1970) and 0.60 by Moss et al. (1998). This shows that all the 19 items were reliable and valid to measure the opinions of consumers towards Online Shopping.

Table 2: Reliability of Measurements Instrument

\begin{tabular}{|l|l|l|}
\hline Scales & Items & Cronbach Alpha \\
\hline Perceived Ease of Use & 3 & 0.802 \\
Perceived Usefulness & 3 & 0.783 \\
Online Shopping Attitude & 3 & 0.752 \\
Online Shopping Intention & 3 & 0.761 \\
Perceived Risk & 7 & 0.828 \\
\hline
\end{tabular}

\section{Results and Analysis}

\subsection{Profile of the Respondents}

Personal and demographic information such as gender, age, income, education level, status, frequency of internet use and potential purchase over the internet are presented in the following table. 
Table 4: Profile of the Respondents

\begin{tabular}{|c|c|c|c|}
\hline Variable & Category & Frequency & Percentage \\
\hline \multirow[t]{2}{*}{ Gender } & Male & 94 & 47.0 \\
\hline & Female & 106 & 53.0 \\
\hline \multirow{6}{*}{ Age } & 15-20 Years & 53 & 26.5 \\
\hline & 20-25 Years & 117 & 58.5 \\
\hline & 25-30 Years & 15 & 7.5 \\
\hline & 30-35 Years & 10 & 5.0 \\
\hline & 35-40 Years & 3 & 1.5 \\
\hline & Above 40 Years & 2 & 1.0 \\
\hline \multirow{6}{*}{ Income } & Below 15000 & 124 & 62.0 \\
\hline & $15000-25000$ & 37 & 18.5 \\
\hline & $25000-35000$ & 17 & 8.5 \\
\hline & $35000-45000$ & 8 & 4.0 \\
\hline & $45000-55000$ & 5 & 2.5 \\
\hline & Above 55000 & 9 & 4.5 \\
\hline \multirow{6}{*}{ Education } & Matriculation & 4 & 2.0 \\
\hline & Inter & 5 & 2.5 \\
\hline & Bachelor & 95 & 47.5 \\
\hline & Master & 71 & 35.5 \\
\hline & MS/ M. Phil & 23 & 11.5 \\
\hline & PHD & 2 & 1.0 \\
\hline \multirow{5}{*}{ Status } & Student & 157 & 78.5 \\
\hline & Employed & 33 & 16.5 \\
\hline & Businessman & 6 & 3.0 \\
\hline & Unemployed & 1 & 0.5 \\
\hline & Housewife & 3 & 1.5 \\
\hline
\end{tabular}




\begin{tabular}{|l|l|l|l|}
\hline & Less than 1 Hour & 36 & 18.0 \\
& $1-2$ Hours & 58 & 29.0 \\
Frequency of Internet & $2-3$ Hours & 42 & 21.0 \\
Use (Hour Per Day) & $3-4$ Hours & 13 & 6.5 \\
& $4-5$ Hours & 24 & 12.0 \\
& More than 5 hours & 27 & 13.5 \\
\hline
\end{tabular}

\subsection{Hypothesis Testing}

\subsubsection{Attitude and Online Shopping Intention}

The results of the regression of the study confirm the significant positive relationship between attitude and on-line purchase intentions with $(\boldsymbol{\beta}=0.554)$ and $(\mathrm{p}=0.000)$. According to these results, the attitude contributes more than $55 \%$ on online purchase intentions. These study results validate $\mathrm{H} 1$.

\subsubsection{Perceived usefulness and Attitude}

According to the study results, Perceived Usefulness has significant positive relation on Attitude with $(\boldsymbol{\beta}=0.235)$, and $(\mathrm{p}=0.004)$. This means that the estimated utility contribute more than $23 \%$ at rest. The results of this study validate the $\mathrm{H} 2$.

\subsubsection{Perceived Ease of Use and Attitude}

According to the results of the research, Perceived Ease of use has a significant positive relationship with attitude. The results of regression perceived ease of use with Attitude is significant with $(\boldsymbol{\beta}=0.211)$ and $(\mathrm{p}=0.000)$. This means that the estimated utility contribute more than $21 \%$ attitude. The results of this study validate the $\mathrm{H} 3$.

\subsubsection{Perceived Ease of Use and Perceived Usefulness}

According to the results of the study, Perceived Ease of use has a significant positive relationship with attitude. The results of regression perceived ease of use with Perceived Usefulness is significant with $(\boldsymbol{\beta}=0.569)$ and $(\mathrm{p}=0.000)$. This means that the estimated utility contribute more than $56 \%$ attitude. The results of this study validate the H4.

\subsubsection{Perceived Risk and Attitude}

Regression analysis model online markets shows that there is significant negative relationship 


\section{Macrothink}

between perceived risk and Attitude with $(\boldsymbol{\beta}=-0.166)$ and $(\mathrm{p}=0.015)$. The above results confirm H5 and we conclude that there is a significant negative relationship between perceived risk and attitude.

\subsubsection{Prior Experience and Perceived Usefulness}

The ANOVA analysis was done to assess the impact of prior experience in the perceived usefulness. According to Anova results, there is no impact of prior experience on perceived usefulness. Based on these results, we reject our H6.

\subsubsection{Prior Experience and Perceived Ease of Use}

The ANOVA analysis was done to assess the impact of prior experience on perceived ease of use. According to Anova results, there is no impact of prior experience on perceived ease of use. Based on these results, we reject our H7.

\subsubsection{Prior Experience and Perceived Risk}

The ANOVA analysis was done to assess the impact of prior experience on perceived risk. According to Anova results, there is no impact of prior experience on perceived risk. Based on these results, we reject our H8.

\subsubsection{Prior Experience and Online Shopping Intention}

The ANOVA analysis was done to assess the impact of prior experience on Online Shopping Intention. According to Anova results, there is no impact of prior experience on Online Shopping Intention. Based on these results, we reject our H9.

Table 6 summarizes the regression results of the study and Figure 2 shows the graphical representation of the structural model.

Table 6: Regression Results

\begin{tabular}{|l|l|l|l|l|l|l|}
\hline Hypothesis & Model Variables & Estimate/ $\boldsymbol{\beta}$ & S.E & C.R & P & Results \\
\hline H1 & $\begin{array}{l}\text { OSI } \\
\text { Attitude }\end{array}$ & 0.554 & 0.064 & 9.370 & 0.000 & Supported \\
\hline H2 & Attitude & 0.235 & 0.073 & 2.931 & 0.004 & Supported \\
\hline
\end{tabular}




\begin{tabular}{|l|l|l|l|l|l|l|}
\hline & PU & & & & & \\
\hline H3 & $\begin{array}{l}\text { Attitude } \\
\text { PEOU }\end{array}$ & 0.211 & 0.068 & 2.646 & 0.009 & Supported \\
\hline H4 & $\begin{array}{l}\text { PU } \\
\text { PEOU }\end{array}$ & 0.569 & 0.054 & 9.745 & 0.000 & Supported \\
\hline H5 & $\begin{array}{l}\text { Attitude } \\
\text { PR }\end{array}$ & -0.166 & 0.070 & -2.947 & 0.015 & Supported \\
\hline
\end{tabular}

Figure 2: Structural Model Results

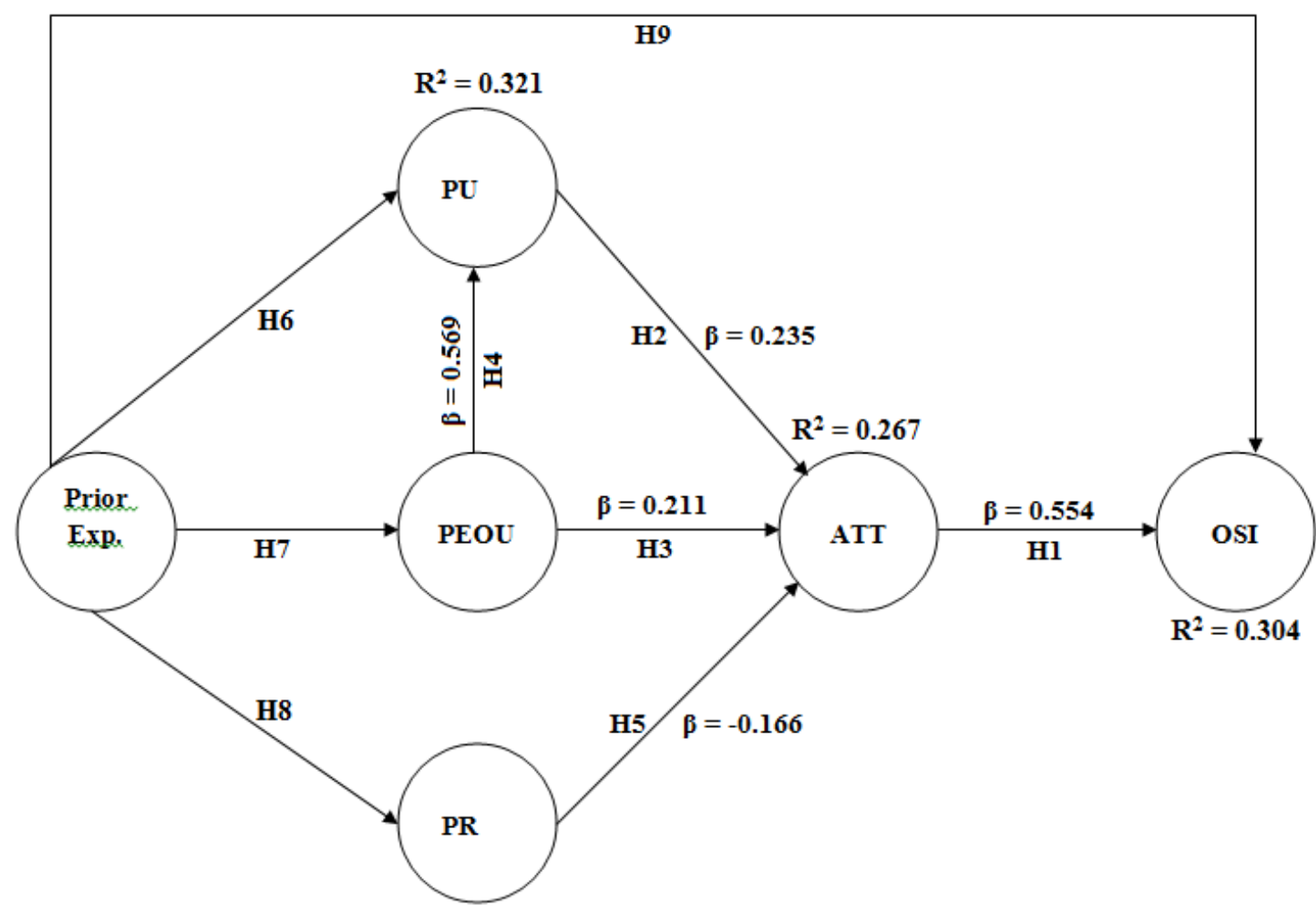




\section{Discussions}

In this script we explain the relationship between these variables i.e. POSI on OSI then POSI influence on PU, PEOU and PR after that these three variable PU, PEOU and PR influence on ATOSI and final ATOSI on OSI. Past scholars say that point OSI terms, Customer perception of privacy has a positive and significant effect on the OSI (Bart et al, 2005. Liu et al, 2005. Romano. 2007). Pakistan is a developing country so developing growth is increase but the growth of OS is not increase as compare to other sector in Pakistan. When people buy a product online does not feel safe they think their credit card (CC) information is hack forexpertshacker's in this way people do not take more intent OS.This script explains that responsiveness positive effect on adoption of OS. When online seller contact to online customer this behave develop the trust of consumer for OS point of view, according to Moorman et al. (1993). Quick response to online purchaser is show that seller is customer-oriented in this way concept of uncertainty is reduce from customer mind.

Amplification show that if POSE is positively increase then PU, PEOU influence positively and significant. Past research show that PEOU and PU has a significantly affect on ATOSI. Consumers trust plays the role of assurance usefulness expected in online atmosphere (Gefen, 1997). In this paper show that PU is highly significant as compare to the PEOU on ATOSI. And also PU is contributing more twenty-four percent in ATOSI and other seventy-six percent contribute other variables. Reason of decreasing OSI in Pakistan is main technology. In Pakistan people do not know in proper way that who to perform OSI, on the other hand OS store introduce new technology to customers for performing OS. Problem is not the new and old technology the main problem in Pakistan for decreasing the trend of OS is that people do not know how to perform OS. If an OS stores provide easy ways to perform OS (PEOU) then the ATOSI is increase as it is the trend of overall business is increasing in Pakistan.

Online customers take more intention when online sellers provide easy to perform online shopping ways and provide useful information. But if online sellers provide easy ways to perform OS then hackers hack CC and such online stores also. If OS stores do not see the strategy other OS stores and products then customers move to competitors, because many OS stores provide same product and services. OS stores minimize the PR through trust then trust enhances behavior of OSI. Another important contribution of this study is the indirect influence of the FUP, PU and PR through ATOSI.On top of result has significant managerial implication. OS stores develop OS user friendly website in this way customers will boost the service and quality consideration. This study is consistent with the previous studies that positive attitude of the online purchaser results in stronger buying intention.

Prior researches (Karahana and Strub, 2003; Gefen and Starub, 2004) explained that PU and PEOU guide to increase of online shopping intention. When customers find the web site and related technology are useful for OS then customers quickly ready to adopt the technology. These findings show that PUF has greater influence on attitude as compare to PEOU. The online 
shopping is truthful and frank and the information given for managing the deal is honest for the online buyer which is expected when PU has positive effect. The customer trust about OS should be increased by PU of the website. (Chircuet al 2000, Gefenet al 2003). The online information helps their customers to making purchase decision and influences OSI that uses internet (Critrin et al, 2003; Shim et al; 2001). This study identifies reasons that hinders and inspire people to carry on or accept OS technology.

Past research explains that prior online shopping experience POSE play a mediating by buyertrust in OS. According to McKnight et al. (2002) and Gefen et al. (2003), when POSE is not more of buyer about E-seller, buyer first trust in OS is further prejudiced by their disposition to trust as compare to direct experience. Personal disposition to trust is explain as a universal propensity to trust others (McKnight et al., 2002). Our search explains that POSE is not directly effect on OSI, according to ANOVA. People of Pakistan has short experience about OS and average frequency of such people one time in a year bought product from online stores. When purchaser has a positive attitude about POSE then purchaser take more interest in OS (Monsuwe et al., 2004; Kim and Stoel, 2004). Low quality product, post-purchase service, unsafe payment system and fake goods were their key complaints. In this way it is explain that way OSI is not increase in Pakistan as compare to others sectors growth in it.

In general, these results emphasize the reasons following the success and failure of the OS. The online information helps their customers to making purchase decision and influences OSI that uses internet. The OS is truthful and frank and the information given for managing the deal is honest for the online buyer which is expected when PU has positive effect. The customer trust about OS should be increased by PU of the website.

\section{Limitations}

This study also has some limitations the first one that it is based on responses from a particular city so the perception of the people living in other cities can be different. The sample size was also small for this study moreover we generally focus on the students.

\subsection{Future Recommendations}

In future studies the researchers can further explain the differences in product categories or can take single product like cloths, electronics for their studies. The future researchers can focus on the different types of risks that can occur during online shopping, e.g. financial risk, product specification risk (color, material, model etc.).Upcoming researchers can further explore the perceived usefulness and perceived ease of use that what the external factors are affecting them.

\section{References}

Ahmed, A., Rehman, U., Rizwan, M., Rafiq, M. Q., Nawaz, M. \& Mumtaz, A. (2013) Moderating Role of Perceived Risk and Innovativeness between Online Shopping Attitude and Intention. Journal of Basic and Applied Scientific Research, 3(11), 310-323 


\section{Macrothink}

Ahn, T., Ryu, S. and Han, I. (2007), “The impact of web quality and playfulness on user acceptance of online retailing", Information \& Management, Vol. 44 No. 3, pp. 263-75.

Ajzen, I. \&Fishbein, M. (1980), Understanding Attitudes \& Predicting Behaviour, New York:

Akhlaq, A. and Ahmed, E. (2011) "Intention Towards Online Shopping: A Pakistan Based Study" (2011). UK academy for Information Systems Conference Proceedings 2011.Paper 1.http://aisel.aisnet.org/ukais2011/1, accessed on (1 January, 2012).

Barkhi R. and Wallace L. (2007) "The impact of personality type on purchasing decision in virtual stores”, Information Technology Management, Vol. 8 No. 4, pp. 313-30.

Bart, Y., Shankar, V., Sultan, F. and Urban, G.L. (2005), "Are the drivers and role of online trustthe same for all web sites and consumers? A large-scale exploratory empirical study”,Journal of Marketing, Vol. 69 No. 4, pp. 133-52.

Bhattacherjee, A. (2001), "An empirical analysis of the antecedents of electronic commerce service continuance", Decision Support Systems, Vol. 32 No. 2, pp. 201-14.

Bauer, 1906, Cox 1976 is not available

Bhatnagar, A., Misra, S. and Rao, H.R. (2000), "On risk, convenience, and internet shopping behaviour", Communications of the ACM, Vol. 43 No. 11, pp. 98-114.

Bhattacherjee, A. (2001). Understanding information systems continuance: an expectation confirmationmodel. MIS Quarterly, 25(3), 351-70.

Brown, M., Pope, N. \&Voges, K. (2003). Buying or browsing? An exploration of shoppingorientations \& online purchase intention.European Journal of Marketing, 37(11), 1666-87.

Burke, R. (2002), "Technology and the customer interface: what consumers want in the physical and virtual store", Academy of Marketing Science Journal, Vol. 30 No. 4, pp. 411-32.

Burner, G.C. \& Kumar, A. (2005)Explaining consumer acceptance of handheld Internet devices. Journal of Business Research, 58(5), 553-568

Burner, G.C. \& Kumar, A. (2005). Explaining consumer acceptance of handheld Internet devices. Journal of Business Research, 58(5), 553-568

Chain Store Age (1999), “The survey says”, Chain Store Age, p. 155.

Cheema, U., Rizwan, M., Jalal, R., Durrani, F. \& Sohail, N. (2013) The Trend of Online Shopping in $21^{\text {st }}$ Century: Impact of Enjoyment in TAM Model, Asian Journal of Empirical Research, 3(2), 131-141 


\section{Macrothink}

Chen, M. (2007) "Consumer attitudes \& purchase intentions in relation to organic foods in Taiwan: moderating effects of food-related personality traits", Food Quality \& Preference, Vol. 18, No. 7, pp. 1008-21.

Cheung, C \& Lee, M. (2000). Trust in Internet shopping: A Proposed Model \& MeasurementInstrument'. In Proceedings of the 2000 Americas Conference on Information Systems(AMCIS), August 3-5, 2000, 681-689.

Chircu, A.M., Davis, G.B. and Kauffman, R.J. (2000), "Trust, expertise and e-commerceintermediary adoption", in DeGross, J. (Ed.), Proceedings of the Sixth Americas Conferenceon Information Systems, ACM, New York, pp. 710-6.

Chiu YB, Lin CP, Tang LL (2005) Gender differs: assessing a model of online purchase intentions in e-tail service. Int. J. service Industry Manag. 16(5).

Cho, J. (2004), "Likelihood to abort an online transaction: influences from cognitiveevaluations, attitudes, and behavioral variables", Information and Management, Vol. 41 No. 7, pp. 827-38.

Creswell, J.W. (1994) Research Design: Qualitative \& Quantitative Approaches. London:SAGE Publications

Critrin et al, 2003 not available

Cyr, D., Head, M. and Ivanov, A. (2006), "Design aesthetics leading to m-loyalty in mobile commerce", Information and Management, Vol. 43 No. 8, pp. 950-63.

Davis, F. D. (1989), "Perceived usefulness, perceived ease of use and users acceptance of information technology", MIS Quartetly, 13(3): 319-340

Davis, F. D. (1993). User acceptance of information technology: system characteristics, user perceptions and behavioral impacts. International Journal of Man-Machine Studies, 38 (3), 982-1003.

Davis, F.D., Bagozzi, R.P. \&Warshaw, P.R. (1989) User acceptance of computer technology: a comparison of two theoretical models. Management Science, 35(8), 982-1003.

Devaraj, S., Fan, M. \&Kohli, R. (2002). Antecedents of B2C channel satisfaction \& devices. Journal of Business Research, 58(5), 553-568

Devaraj, S., Fan, M. \&Kohli, R. (2002). Antecedents of B2C channel satisfaction \& preference: validating e-commerce metrics. Information System Research, 13(3), 316-33.

Dowling, G.R. and Staelin, R. (1994), "A model of perceived risk and intended risk handling activity”, Journal of Consumer Research, Vol. 21 No. 1, pp. 119-34.

Eastlick, M. and Lotz, S. (1999), "Profiling potential adopters and non-adopters of an interactiveelectronic shopping medium", International Journal of Retail \& Distribution Management, Vol. 27 No. 6, pp. 209-23. 
Fishbein, M. \&Ajzen, I. (1975), Belief, Attitude, Intention, \& Behavior: An Introduction to

Theory \& Research, Reading, MA: Addison-Wesley.

Forsythe SM, Shi B (2003).Consumer patronage and risk perceptions in Internet shopping. J. Bus. Res. 56: 867-875.

Garbarino E, Strabilevitz M (2004), Gender Differences in the Perceived Risk of Buying Online and the Effects of Receiving a Site Recommendation. J. Bus. Res. 57: 768-775.

Gefen and Starub, 2004 not available

Gefen, D. (1997), "Building users' trust in freeware providers and the effects of this trust on users' perceptions of usefulness, ease of use and intended use of freeware", $\mathrm{PhD}$ thesis, Georgia State University, Atlanta, GA.

Gefen, D. (2003), "TAM or just plain habit: a look at experienced online shoppers", Journal of End User Computing, Vol. 15 No. 3, pp. 1-13.

Gefen, D., Karahanna, E. and Straub, D.W. (2003), "Trust and TAM in online shopping: anintegrated model”, MIS Quarterly, Vol. 27 No. 1, pp. 51-90.

Geuens, M., Brengman, M. and S'Jegers, R. (2003), "Food retailing: now and in thefuture: a consumer perspective", Journal of Retailing and Consumer Services, Vol. 10 No. 4,pp. 241-51.

Gofen 2003 is not available

Hoffman D.L., Novak, T.P. \& Schlosser, A. (2003). Consumer attitudes toward software filters \& online content ratings: a policy analysis. Journal of Public Policy \& Marketing, 22(1), 41-57.

Horton, R.L. (1976), “The structure of perceived risk", Journal of the Academy ofMarketing Science, Vol. 4 No. 4, pp. 694-706.

Huang WY, Schrank H, Dubinsky AJ (2004), Effect of Brand Name on Consumers_ Risk Perceptions of Online Shopping. J. Consumer Behavior 4(1):40-50.

Hubona, G.S. \&Kennick, E. (1996).The impact of external variables on information technology usage behavior.IEEE Proceedings of the Hawaii International Conference on System Sciences, 4, 166-75.

Kwon, K. \& Lee, J. (2003). Concerns about payment security of Internet purchases: a perspective on current on-line shoppers. Clothing \& Textiles Research Journal, 21(4), 174-84.

Lee, G. G. and Lin H. F. (2005), "Customer perceptions of e-service quality in online shopping", International Journal of Retail \& Distribution Management,Vol. 33 No. 2, pp. 161-176. 
Lee, H. G. and Clark T. H. (1996) "Economic Benefits and Adoption Barriers of Electronic Market Systems", Ninth International EDI-IOS Conference, Bled, Slovenia.

Lee, H.-J.and Huddleston, P. (2006), "Effects of e-tailer and product type on risk handling in

online shopping”, Journal of Marketing Channels, Vol. 13 No. 3, pp. 5-12.

Lee, S., Katerattanakul, P. and Hong, S. (2005) 'Framework for User Perception of Effective E-tail Web Sites,' Journal of Electronic Commerce in Organizations, 3 (1), 13-34.

Lim, H. and Dubinsky, A.J. (2004), “Consumers' perceptions of e-shopping characteristics: an expectancy-value approach”, Journal of Services Marketing, Vol. 18 No. 7, pp. 500-13.

Lim, N. (2003), "Consumers' perceived risk: sources versus consequences",Electronic Commerce Research and Applications, Vol. 2 No. 3, pp. 216-28.

Limayem, M., Khalifa, M. \&Frini, A. (2000). What makes consumers buy from internet? A longitudinal study of online shopping”, IEE Transactions on Systems, Man \& Cybernetics, Part

A. Systems \& Humans, 30(4), 421-32

Limayem, M., Khalifa, M. \&Frini, A. (2003) not available

Liu, C., Marchewka, J.T., Lu, J. and Yu, C.S. (2005), "Beyond concern: a privacy-trust behavioral intention model of electronic commerce", Information \& Management, Vol. 42 No. 2, pp. 127-42.

Limayem, M., Khalifa, M. \&Frini, A. (2000). What makes consumers buy from internet? A longitudinal study of online shopping”, IEE Transactions on Systems, Man \& Cybernetics, Part

A. Systems \& Humans, 30(4), 421-32.

Lorek, L.A. (2003), "Buyers catch on to online shopping", San Antonio Express-News, available at: http://web.lexis-nexis.com/universe/document (accessed 22 December 2003).

Lee, H.-J.and Huddleston, P. (2006), "Effects of e-tailer and product type on risk handling 
in

online shopping", Journal of Marketing Channels, Vol. 13 No. 3, pp. 5-12.

Lorek, L.A. (2003), "Buyers catch on to online shopping", San Antonio Express-News, available at: http://web.lexis-nexis.com/universe/document (accessed 22 December 2003).

Lymet 2010 not available

M. SajidBhatti 2013 not available

Magee, M. (2003), “Boom or bust for e-shopping”, The Sunday Tribune, available at: http:// web.lexis-nexis.com/universe/document (accessed 22 December 2003).

Malhotra et al. 2004 and Drennan et al. 2006 is not available

Magee, M. (2003), “Boom or bust for e-shopping”, The Sunday Tribune, available at: http:// web.lexis-nexis.com/universe/document (accessed 22 December 2003).

Maloy, T.K. (2003), "Net is here to stay for retailers", available at: http://web.lexis-nexis.com/

universe/document (accessed 22 December 2003).

McKechnie, S., Winklhofer, H. \&Ennew, C. (2006) Applying the technology acceptance model to the online retailing of financial services.International Journal of Retail \& Distribution Management, 34(4), 388-410.

Miyazaki, A.D. and Ferna'ndez, A. (2001), "Consumer perceptions of privacy and security risksfor online shopping”, The Journal of Consumer Affairs, Vol. 35 No. 1, pp. 27-44.

Monsuwe TP, Dellaert BGC, de Ruyter KR (2004), What drives consumers to shop online? A literature review. Int. J. Services industry Manag. 15(1): 102-121.

Moon, J.W. and Kim, Y.G. (2001), "Extending the TAM for a world wide web context", Information \& Management, Vol. 38 No. 4, pp. 217-30.

Moorman, C., Deshpande, R. and Zaltman, G. (1993), "Factors affecting trust in marketrelationships”, Journal of Marketing, Vol. 57 No. 1, pp. 81-101.

Morris, M.G. and Venkatesh, V. (2000), “Age differences in technology adoption decisions: Implications for a changing work force”, Personnel Psychology, Vol. 53 No. 2, pp. 375-403.

Moss, S., Prosser, H., Costello, H. (1998). Reliability and validity of the PAS-ADD Checklist for detecting psychiatric disorders in adults with intellectual disability.Journal of IntellectualDisability Research.42, 173-183.

Nunnally, JC. (1970). Introduction to Psychological Measurement. New York: McGraw-Hill. Nurosis M. (1993), Statistical Data Analysis, SPSS, New York, NY. 


\section{Macrothink}

Journal of Sociological Research ISSN $1948-5468$ 2014, Vol. 5, No. 1

O'Cass, A. and Fenech, T. (2003), "Web retailing adoption: exploring the nature of internet usersweb retailing behaviour", Journal of Retailing and Consumer Services, Vol. 10, pp. 81-94.

Park, C. \& Jun, J. (2003). A cross-cultural comparison of internet buying behavior: effects of internet usage, perceived risks, \& innovativeness. International Marketing Review, 20(5), 534- 53.

Park, J., Lee, D. and Ahn, J. (2004), "Risk-focused e-commerce adoption model: a cross-countrystudy", Journal of Global Information Technology Management, Vol. 7 No. 2, pp. 6-30.

Pavlou, P. (2003). Consumer acceptance of electronic commerce: integrating trust \& risk with the technology acceptance model. International Journal of Electronic Commerce, 7(3), 101- 134.

Radner, R. and M. Rothschild, (1975) On the allocation of effort. Journal of Economic Theory 10,358-376.

Retail Merchandiser (2003), "Online spending jumps 18 per cent", Retail Merchandiser, available at: http://web.lexis-nexis.com/universe/document (accessed 22 December 2003).

Retailing, Vol. 76 No. 3, pp. 309-22.

Retail Merchandiser (2003), "Online spending jumps 18 per cent", Retail Merchandiser, available at: http://web.lexis-nexis.com/universe/document (accessed 22 December 2003).

Rogers, E.M. (1962), Diffusion of Innovations, Macmillan, New York, NY.

Romano 2007 not availvble

Rowley I (2000), Product search in e-shopping: A review and research propositions. J. consumer Marketing 17, 20-35.

Rowley, J. (2000), "Product searchingwith shopping bots", Internet Research,Vol. 10No. 3,pp. 203-14.

Rowley, M.L. and Okelberry, A. (2000), "Shopping.com: analysis of a trend", Journal of Family and Consumer Sciences, Vol. 92 No. 1, pp. 9-10.

Schlosser AE (2003), Experiencing products in the virtual world-the role of goal and imagery in influencing attitudes. J. Consumer Res. 30 (2): 184-198.

Shim SMA, Eastlicks.ll PW (2001),An online pre-purchase intentions model: The role of intention to search. J. Retailing 77: 397-416.

Shin, D. H. (2009). Towards an understanding of the consumer acceptance of mobile wallet.

Computers in Human Behavior, 25(6), 1343-54.

Siddiqui, N., O’Malley, A., McColl, J.C. and Birtwistle, G. (2003), "Retailer and consumer 


\section{Macrothink}

Journal of Sociological Research

ISSN 1948-5468

2014, Vol. 5, No. 1

perceptions of online fashion retailers: web site design issues", Journal of FashionMarketing and Management, Vol. 7 No. 4, pp. 345-55.

Szymanski, D.M. and Hise, R.T. (2000), "E-satisfaction: an initial examination", Journal of

Theory \& Research, Reading, MA: Addison-Wesley.

Venkatesh, V. and Morris, M.G. (2000), "Why don't men ever stop to ask for directions?. Gender, social influence, and their role in technology acceptance and usage behaviour", MIS

Quarterly, Vol. 24 No. 1, pp. 115-39.

Van den Poel, D. \&Leunis, J. (1999).Consumer acceptance of the internet as a channel of distribution.Journal of Business Research, 45 (3), 249-256.

Venkatesh V. (2000). Determinants of perceived ease of use: integrating control, intrinsic motivation\& emotion into the technology acceptance model. Information Systems Research, 11(2), 342-65.

Venkatesh, V., Morris, M. and Ackerman, P.L. (2000), “A longitudinal field investigation ofgender differences in individual technology adoption decision making processes", Organizational

Venkatesh, V. and Davis, F.D. (2000), "A theoretical extension of the technology acceptance model: four longitudinal field studies”, Management Science, Vol. 46 No. 2, pp. 186-204.

Weber, K. and Roehl, W.S. (1999), "Profiling people searching for the purchasing travel products on the World Wide Web", Journal of Travel Research, Vol. 37 No. 3, pp. 291-8.

Wolfinbarger, M. \&Gilly, M. (2001).Shopping online for freedom, control, \& fun.California Management Review, 43(2), 34-56.

Wood, S.L. (2002). Future fantasies: a social change perspective of retailing in the $21 \mathrm{st}$ century. Journal of Retailing, 78(1), 77-83.

Yu 2005 not available

Zhou, L., Dai, L. and Zhang, D. (2007), "Online shopping acceptance model: a critical survey ofconsumer factors in online shopping", Journal of Electronic Commerce Research, Vol. 8Zikmund, W.R. (1997). Business Research Methods (5th Ed.), Texas: The Dryden Press. 